\title{
STOSUNKI MIĘDZY PAŃSTWEM A ZWIĄZKAMI WYZNANIOWYMI W NIEPODLEGŁEJ UKRAINIE (1991-2013)
}

Ogłoszenie przez Ukrainę Deklaracji Niepodległości w 1991 r. było początkiem procesu zmian, które dotyczyły wszystkich dziedzin życia społeczno-politycznego. Sferą, która także wymagała uregulowania, była kwestia relacji pomiędzy państwem i związkami wyznaniowymi. Dotychczasowe rozwiązania, sięgające korzeniami uregulowań z okresu ZSRR, nie były odpowiednie dla transformacji ustroju państwa w kierunku demokratycznym. Ponadto, trzeba zauważyć, że Ukraina jest państwem wielowyznaniowym i niejednokrotnie podziały religijne nakładają się i współwystępują z podziałami politycznymi.

Ponad 70\% mieszkańców Ukrainy określa się mianem prawosławnych. Zwrócić należy uwagę, że są oni podzieleni pomiędzy kilka związków wyznaniowych ${ }^{1}$. Najliczniejsza jest Ukraińska Cerkiew Prawosławna (Patriarchatu Moskiewskiego) - Українська Православна Церква (Московський Патріархат)². Cerkiew ta ma około 12000 parafii i ponad 9600 duchownych $^{3}$. Drugim pod względem wielkości jest

* Dr, Instytut Religioznawstwa, Uniwersytet Jagielloński, ul. Grodzka 52, 31-044 Kraków, e-mail: strutynski@o2.pl

${ }^{1}$ Szczegółowe informacje dotyczące genezy tej sytuacji zob. A. Szeptycki, Podziaty religijne na Ukrainie, w: Religia $w$ stosunkach międzynarodowych, red. A.M. Solarz, H. Schreiber, Warszawa 2012.

${ }^{2}$ Określenie „Patriarchatu Moskiewskiego” nie znajduje się w oficjalnym nazewnictwie Cerkwi. Jest używane dla zaznaczenia przynależności.

${ }^{3}$ Ukrajinska Prawosławna Cerkwa, http://risu.org.ua/ua/index/reference/major_religions/ \%D0\%A3\%D0\%9F\%D0\%A6+\%28\%D0\%9C\%D0\%9F\%29/42922/ [dostęp: 2.04.2014]. Procentowo kształtowało się to następująco: 2000 - 9,2\%, 2005 - 10,6\%, 2010 - 23,6\%, 2013 - 19,6\%, Relihija i wlada w Ukrajini. Informacijni matariali do Kryhtoho stolu na temy 
Ukraińska Cerkiew Prawosławna (Patriarchatu Kijowskiego). Należy do niej ponad 4300 parafii oraz około 10 milionów wiernych ${ }^{4}$. Trzecim Kościołem prawosławnym jest Ukraińska Autokefaliczna Cerkiew Prawosławna (Українська Автокефальна Православна Церква). Posiada ona około 1200 parafii oraz 700 duchownych $^{5}$. Na Ukrainie funkcjonuje także Ukraińska Cerkiew Greko-Katolicka (Українська греко-католи́цька церква) do której należy ponad 3600 parafii i ponad 2400 duchownych $^{6}$. Kolejnym dość licznym wyznaniem jest Kościół Rzymskokatolicki (Римсько-Католицька Церква), którego stan posiadania szacuje się na 900 parafii oraz około 580 duchownych. Ponad 90\% mieszkańców państwa ukraińskiego należy do wyznań chrześcijańskich. Oprócz prawosławnych (także ze wspólnot tu niewymienionych) oraz katolików (obrządku wschodniego i łacińskiego) obecni są także przedstawiciele wyznań protestanckich: baptyści, zielonoświątkowcy, luteranie oraz kalwini. Prócz wyznawców chrześcijaństwa na Ukrainie notuje się przedstawicieli islamu, judaizmu, buddyzmu czy neopogaństwa.

Wielość wyznań i panujące pomiędzy nimi napięcie może przyczynić się według niektórych badaczy do rozwoju tendencji separatystycznych. W. Pawluczuk w książce Ukraina. Polityka i mistyka przytacza słowa ukraińskiego naukowca M. Chmyłowskiego, który w pierwszej połowie lat dziewięćdziesiątych XX w. stwierdził, że: „Biorąc pod uwagę obecność na Ukrainie daleko idących zróżnicowań regionalnych w świadomości i sposobie bycia, sformowanie się jeszcze tego rodzaju «regionalno-państwowych» kościołów może stać się tym czynnikiem, który spowoduje przekroczenie krytycznej masy regio-

Derżawno konfesijni widnosyny w Ukrajini stanom na 2013 rik: ruch do partnerstwa derżawy i Cerkwy czy do kryzy wzajemin?, Kyjiw 2013, s. 27.

${ }^{4}$ Istorija Ukrajinskoji Prawosławnoji Cerkwy - Kijowskoho Patriarchatu, http://risu. org.ua/ua/index/reference/major_religions/ \%D0\%A3\%D0\%9F\%D0\%A6+\%D0\%9A\%D0\%9F/45457/, [dostęp: 2.04.2014]. Statystki informują, że w 2000 należało do niej $12,1 \%$, w 2005 - 14,0\%, w 2010 - 15,1\%, a w 2013 - 18,3\%, Relihija i wlada w Ukrajini. Informacijni matariali, s. 27.

5 Українська Автокефальна Православна Церква, http://risu.org.ua/ua/index/reference/ major_religions/ \%D0\%A3\%D0\%90\%D0\%9F\%D0\%A6/33294/, [dostęp: 2.04.2014].

${ }^{6}$ Українська греко-католи́цька церква, http://risu.org.ua/ua/index/reference [dostęp: 2.04.2014]. 
nalizmu na Ukrainie i jego przejście ze stanu potencjalności w stan aktywny. Co więcej, same hasła obrony «naszej cerkwi, naszej wiary» mogą poderwać miliony, stać się ideowym podłożem separatyzmu (...)"’7. Wprawdzie na współczesnej Ukrainie nie obserwujemy ruchów separatystycznych, których wyłączną siłą napędową byłaby religia, tym niemniej bywa ona często składnikiem pewnych postaw politycznych.

Niezwykle ważną instytucją na Ukrainie, w kontekście relacji pomiędzy państwem a związkami wyznaniowymi, jest powstała w 1996 r. Ogólnoukraińska Rada Cerkwi i organizacji religijnych (Всеукраїнська Рада Церков і релігійних організацій), która stara się mieć wpływ na stosunki pomiędzy państwem i związkami wyznaniowymi oraz przeciwdziałać niekorzystnym dla nich rozwiązaniom. Organizacją skupiającą wyłącznie kościoły chrześcijańskie jest natomiast Konferencja Chrześcijańskich Kościołów Ukrainy ${ }^{8}$.

Prawnymi gwarantami wolności sumienia i wyznania są konstytucja oraz ustawa $\mathrm{O}$ wolności sumienia $\mathrm{i}$ organizacjach religijnych (Про свободу совісті та релігійні організаціï). Konstytucja stanowi prawny fundament demokratycznego państwa. Nowa konstytucja ukraińska została uchwalona na piątej sesji Rady Najwyższej w dniu 28 czerwca 1996 r. ${ }^{9}$ Kwestii ochrony wolności sumienia i wyznania został poświęcony art. 35, który głosi: „Każdy ma prawo do swobodnego wyboru światopoglądu i wyznania. Prawo to obejmuje wolność wyznawania dowolnej religii albo niewyznawania żadnej, uczestniczenia bez przeszkód pojedynczo lub grupowo w praktykach i obrzędach religijnych, prowadzenia działalności religijnej.

Korzystanie z tego prawa może zostać ograniczone ustawą tylko w interesie ochrony porządku publicznego, zdrowia i moralności publicznej albo obrony praw i wolności innych ludzi.

${ }^{7}$ Римо-Католицька Церква в Україні, http://risu.org.ua/ua/index/reference/major religions/ \%D0\%A0\%D0\%9A\%D0\%A6/47363/ [dostęp: 2.04.2014].

${ }^{8}$ M. Chmyłowśkyj, Relihija w Ukrajini: stan i perspektywy, w: Druhyj Miżnarodnyj Konhres Ukrajinistiw, Lwiw 1994, cyt. za W. Pawluczuk, Ukraina. Polityka i mistyka, Kraków 1998, s. 123.

${ }^{9}$ Zob. T. Szyszlak, Lwowskie sacrum, kijowskie profanum. Grekokatolicyzm w ukraińskiej przestrzeni publicznej od pierestrojki do pomarańczowej rewolucji, Warszawa 2012, s. 176-180. 
Kościół i organizacje religijne na Ukrainie są oddzielone od państwa, a szkoła - od Kościoła. Żadna religia nie może być uznana przez państwo za panującą.

Nikt nie może zostać zwolniony z obowiązków wobec państwa ani odmówić wykonywania postanowień ustaw z powodu przekonań religijnych. Jeżeli wypełnienie obowiązku służby wojskowej pozostaje w sprzeczności z przekonaniami religijnymi obywatela, wykonanie tego obowiązku winno zostać zastąpione służbą zastępczą (niewojskową)"10.

Można zauważyć tu pewne podobieństwa do sformułowań zawartych w polskiej ustawie $\mathrm{z}$ dnia 17 maja 1989 r. o gwarancjach wolności sumienia i wyznania, jak również do treści obecnych w konstytucji USA. Wyraźnie został zaznaczony rozdział państwa od kościoła, jak również szkoły od cerkwi.

Drugim bardzo ważnym aktem jest ustawa z dnia 23 kwietnia $1991 \mathrm{r}$. o wolności sumienia i organizacjach religijnych ${ }^{11}$. Ustawa ta była kilkukrotnie nowelizowana, a najwięcej dyskusji i głosów krytycznych ze strony związków wyznaniowych wywołała zmiana ustawy, która miała miejsce w 2012 r. za czasów prezydentury Wiktora Janukowycza. Warto w tym miejscu zauważyć, że prezydenci Ukrainy wywierają dość znaczny wpływ na kształtowanie się relacji między państwem a związkami wyznaniowymi.

Uzyskanie niepodległości zmusiło państwo ukraińskie do wypracowania własnego modelu stosunków państwo - kościół. J. Babinow stwierdził, że: „Polegając na doświadczeniu światowym Ukraina stara się budować własną politykę państwową w stosunku do religii i Cerkwi na bazie praworządności i sprawiedliwości społecznej, a szczególnie na zasadach: zgody i współpracy obywateli niezależnie od ich stosunku do religii; stworzenia sprzyjających warunków dla działalności organizacji religijnych; rozwoju społecznej moralności i humanizmu; równych praw i możliwości dla wszystkich organizacji religijnych na bazie sprawiedliwości społecznej; wzajemnej religijnej i światopoglądowej tolerancji i szacunku między wierzącymi i niewierzącymi (...) szacun-

${ }^{10}$ Відомості Верховної Ради України (ВВР), 1996, о 30, ст. 141 із змінами.

${ }^{11}$ Tekst w j. polskim za: Konstytucja Ukrainy, tłum. E. Toczek, A. Kubik, Warszawa 2014. 
ku państwa wobec tradycji i wewnętrznych postanowień organizacji religijnych; równości wobec prawa wszystkich organizacji religijnych; stworzenia warunków dla uczestnictwa organizacji religijnych w życiu społecznym (...)"'12.

W pełni demokratyczne założenia wzajemnych państwowo-kościelnych relacji nie zawsze udaje się, na co zwracają uwagę obserwatorzy ukraińskiego życia politycznego, spełnić. Historyczne zaszłości dają o sobie znać także i w tej dziedzinie. Ma na nie również wpływ bieżąca polityka, co niejednokrotnie przekłada się na nierówne traktowanie związków wyznaniowych przez państwo.

Zagadnienia stosunków między państwem i związkami wyznaniowymi oraz zapewnienia wolności sumienia i wyznania są tematem zainteresowania organizacji religijnych oraz niezależnych instytucji, które monitorują przestrzeganie wolności obywatelskich przez państwo. Należy do nich między innymi ukraińska Helsińska Fundacja Praw Człowieka, Instytut Wolności Religijnej (Інститут релігійної свободи) $)^{13}$ oraz Centrum Razumkowa (Український центр економічних і політичних досліджень імені Олександра Разумкова) ${ }^{14}$. Związki wyznaniowe oraz wspomniane organizacje pozarządowe regularnie dokonują oceny przestrzegania przez państwo wolności wyznania, a także formułują własne postulaty. Kościoły na Ukrainie, przede wszystkim dotyczy to kościołów prawosławnych, są niezwykle wyczulone na kroki władz państwowych, które według nich uprzywilejowują jeden z kościołów.

J. Babinow wyraził przekonanie, że funkcjonująca dowolność interpretacji ukraińskiego prawodawstwa wyznaniowego i brak konkretnych mechanizmów jego realizacji przyczynia się do przekonania: „(...) przedstawicieli wielu wyznań o nieprzestrzeganiu proklamowanej przez państwo zasady równości wszystkich religii”'15. Cytowany autor

12 BВP 1991, No 25, ст.283 із змінами.

${ }^{13}$ J.A. Babinow, Poszukiwania ukraińskiego modelu stosunków państwowo-religijnych, „Nomos” 2001, nr 34-36, s. 13.

${ }^{14}$ Został założony w 2001 r. w Kijowie. Twórcą był Oleksandr Zajec.

${ }^{15}$ Organizacja powstała w 1994 r., pod obecną nazwą funkcjonuje od 2000 r. Zajmuje się analizą ukraińskiej polityki w różnych wymiarach (m.in ekonomicznym, wojskowym, społecznym). 
zauważał także, że: „Liderzy Cerkwi prawosławnych wciąż żądają od rządzących państwem protekcjonizmu państwowego w stosunku do Ukraińskiej Cerkwi Prawosławnej. Powołują się przy tym na fakt, że należy do niej większość wierzących, że w ciągu wieków prawosławie odcisnęło piętno na charakterze narodu ukraińskiego"16.

Nie należy przy tym zapominać, że ukraińscy politycy starali się o przychylność Cerkwi mając równocześnie nadzieję na scementowanie narodu przez prawosławie. Wyodrębnienie się Ukraińskiej Cerkwi Prawosławnej Kijowskiego Patriarchatu (UCP KP) zostało bardzo przychylnie przyjęte przez władze ukraińskie, łącznie z prezydentem Leonidem Krawczukiem ${ }^{17}$. Wydaje się, że politycy ukraińscy traktowali Kościoły dość instrumentalnie. Wystarczy zauważyć, że w 1994 r. UCP KP straciła poparcie władz. Natomiast kandydaci na urząd prezydenta, L. Krawczuk i L. Kuczma, starali się pozyskać przychylność Ukraińskiej Cerkwi Prawosławnej Patriarchatu Moskiewskiego (UCP PM) ${ }^{18}$.

Można powiedzieć, że większość komentatorów na Ukrainie dość pozytywnie oceniała państwową politykę wyznaniową do 2010 r. Opublikowane przez Centrum Razumkowa w kwietniu 2013 r. materiały Religia i władza na Ukrainie: problemy wzajemnych relacji krytycznie odnosiły się do prezydentury Wiktora Janukowycza. Wcześniejszy okres był przez analityków Centrum Razumkowa oceniany dużo lepiej. Zwracano uwagę na uchwalenie w tym czasie ustawy o wolności wyznania i organizacjach religijnych, do której wprowadzono kilka zmian nienaruszających jej istoty ${ }^{19}$. Miał także miejsce dialog pomiędzy wyznaniami - zwłaszcza skupionymi w Ogólnoukraińskiej Radzie Cerkwi i Organizacji Religijnych - a organami państwa. Ponadto, ustaliła się tradycja spotkań przedstawicieli wyznań z naczelnymi władzami państwa, w tym z Prezydentem Ukrainy ${ }^{20}$. Brak spotkania z prezydentem, mimo wcześniejszej deklaracji z jego strony, został bardzo źle przyjęty przez przedstawicieli związków wyznaniowych.

\footnotetext{
${ }^{16}$ J. Babinow, Poszukiwania, s. 15.

17 Tamże.

${ }^{18}$ W. Pawluczuk, Ukraina, s. 144.

19 Tamże, s. 145.

${ }^{20}$ Relihija $i$ wlada w Ukrajini: problemy wzajemowidnosyn, kwiteń 2013, s. 4.
} 
Ponadto, prezydent W. Janukowycz spotkał się jedynie z przedstawicielami Rosyjskiej Cerkwi Prawosławnej oraz UCP PM.

Raport Centrum Razumkowa wskazywał także na wzmożoną aktywność ze strony rosyjskiego prawosławia przejawiającą się m.in. w wizytach patriarchy Cyryla na Ukrainie. Jak zaznaczono, w 2010 r. miały miejsce 3 wizyty, w tym jedna połączona $\mathrm{z}$ inauguracją prezydentury Janukowycza ${ }^{21}$. Prezydentura W. Janukowycza spotykała się ze zdecydowaną krytyką. Uważano, że prezydent łamie zasadę współpracy ze wszystkimi związkami wyznaniowymi, wyraźnie faworyzując jeden z nich. Także inne posunięcia W. Janukowycza były odbierane jako zamach na dotychczasową politykę wyznaniową. Można powiedzieć, że wcześniejsze lata, przed objęciem rządów przez W. Janukowycza, jawiły się związkom wyznaniowym jako korzystny czas dla ich działalności i relacji pomiędzy nimi a państwem. Rzecz jasna nie oznacza to, że w latach dziewięćdziesiątych i po roku 2000 nie było pewnych niedociągnięć we wzajemnych relacjach.

Wcześniejsze raporty generowane przez związki wyznaniowe i organizacje pozarządowe pozytywnie oceniały wyznaniową politykę Ukrainy. W 2006 r. Religijno-informacyjna służba Ukrainy (Релігійноінформаційна служба України, RISU) analizując podejście władz do kwestii wyznaniowych w 2005 r. nie wysuwała większych zastrzeżeń. Podkreślano zwłaszcza rolę prezydenta Wiktora Juszczenki jako aktywnego gwaranta wolności wyznania. Wspomniano jego kontakty z Ogólnoukraińską Radą Kościołów oraz wydane dokumenty dotyczące sfery wyznaniowej: W sprawie działań na rzecz realizacji polityki państwa w dziedzinie stosunków międzynarodowych, religii i Kościoła (Про заходи щодо реалізації державної політики в сфері міжнаціональних відносин, релігій і Церкви) z 23 września 2005 r. i W sprawie pilnych działań w celu wzbogacenia i rozwoju kultury i duchowości ukraińskiego społeczeństwa (Про першочергові заходи щодо збагачення та розвитку культури і духовності українського суспільства) z 24 listopada 2005 r. $^{22}$

${ }^{21}$ Tamże.

${ }^{22}$ Tamże, s. 5. W raporcie podkreślono, że także strona rosyjska obecność patriarchy Cyryla i jego błogosławieństwo dla nowego prezydenta traktowały jako manifestację polityczną. 
W 2005 r. miała także miejsce zauważalna zmiana w sferze relacji pomiędzy państwem a religiami. Doszło do, krytykowanej przez wielu analityków, reorganizacji Państwowego Komitetu Ukrainy do spraw religii (Державний комітет у справах релігій). Prezydent Juszczenko podpisał ustawę Nr 701 W sprawie Ministerstwa Sprawiedliwości Ukrainy (Про питання Міністерства юстиції України), która przekazywała funkcje Komitetu Ministerstwu Sprawiedliwości Ukrainy. Następnie rząd postanowił o utworzeniu Państwowego departamentu do spraw religii w ramach Ministerstwa Sprawiedliwości ${ }^{23}$. T. Antoszewskij i L. Kowalenko po analizie statutu tego departamentu zauważyli, że: „(...) jedyną realną zmianą jest obniżenie statusu tego organu państwowego urzędu oraz mniej precyzyjnie sformułowane kompetencje"24.

Trzeba zresztą zauważyć, że problem administracji wyznaniowej jawi się jako jeden z ważnych punktów w rozważaniach na temat ukraińskiego prawa wyznaniowego. Oczywiste jest, że sprawna administracja oparta na przejrzystych podstawach prawnych jest niezwykle ważna dla właściwej realizacji stosunków pomiędzy państwem a związkami wyznaniowymi. W wypowiedziach przedstawicieli ukraińskich konfesji i badaczy relacji państwowo-wyznaniowych niejednokrotnie pojawia się kwestia braku przemyślanej administracji wyznaniowej. Zmiany, takie jak ta w 2005 r., nie przyczyniały się do ustabilizowania sytuacji. Można zaryzykować twierdzenie, że ukraiński prawodawca nie do końca miał jasną koncepcję, gdzie w hierarchii administracyjnej winny znaleźć się sprawy wyznaniowe ${ }^{25}$. W 2010 r. doszło do zasadniczej zmiany, gdyż prezydent W. Janukowycz w grudniu 2010 r. zadecydował o likwidacji Państwowego Komitetu Ukrainy do spraw religii. Doszło przy tym do podziału jego kompetencji. Część odpowiedzialna za realizację państwowej polityki w stosunku do religii została przyporządkowana Ministerstwu Kultury, a część odpowiedzialna za

${ }^{23}$ T. Antoszewskij, L. Kowalenko, Monitoring relihijnoji swobody w Ukrajini: osoblywyj ohljad na majnowi pytannja, Lwiw 2005-2006, s.14, http://www.irs.in.ua/index. php?option $=$ com_content $\&$ view $=$ article $\&$ id $=124 \% 3 \mathrm{~A} 1 \&$ catid $=38 \% 3 \mathrm{Apub} \&$ Itemid $=65 \& 1$ ang=uk [dostęp: 12.05.2014].

${ }^{24}$ Tamże.

${ }^{25}$ Tamże. 
rejestrację związków wyznaniowych Państwowej Służbie Rejestracji Ukrainy $^{26}$. Zmiana ta wywołała niezadowolenie związków wyznaniowych, z którymi zagadnienie to nie było konsultowane. Ponadto, w ocenie jej krytyków miała spowodować komplikacje m.in. przy rejestracji związków wyznaniowych.

Cytowany raport z 2006 r. pozytywnie odnosił się także do rozwoju regionalnego poziomu kontaktów administracji państwowej z przedstawicielami związków wyznaniowych. Zauważono, że prezydent poważnie potraktował tę kwestię zlecając szefom administracji terenowej zorganizowanie w ciągu 15 dni lokalnych rad i zaproszenie do nich przedstawicieli związków wyznaniowych ${ }^{27}$. Okres prezydentury W. Juszczenki był oceniany dobrze. Dostrzegano zaangażowanie prezydenta w relacje z przedstawicielami związków wyznaniowych na równych zasadach bez faworyzowania któregoś z nich. Ta dobra ocena postawy prezydenta i rządowej administracji nie oznacza, że nie było konfliktów o podłożu wyznaniowym. Te jednak bardziej dotyczyły relacji międzykonfesyjnych (przede wszystkich pomiędzy UCP PM a UCP KP), a nie relacji z państwem. Przy okazji omawiania tworzenia regionalnych rad do współpracy ze związkami wyznaniowymi zauważono, że taki organ nie powstał we lwowskiej obłasti, w której występuje sporo konfliktów państwowo-wyznaniowych i międzywyznaniowych ${ }^{28}$. Konflikty miały przede wszystkim miejsce lokalnie, a nie na szczeblu krajowym ${ }^{29}$.

Zasadniczą kwestią, która praktycznie od początku lat dziewięćdziesiątych XX w. nie została rozwiązana i budzi wiele emocji, jest zwrot majątków kościołom na Ukrainie. Nie chodzi przy tym jedynie o materialną wartość mienia (choć jest to także bardzo ważny element), ale także o symbolikę historyczną. Rywalizacja ma miejsce przede wszystkim pomiędzy cerkwią podległą Patriarchatowi Moskiewskiemu a cerkwią Patriarchatu Kijowskiego.

${ }^{26} \mathrm{O}$ historii ukraińskiej administracji wyznaniowej zob. L. Vladyczenko, Do istoriji derżawnoho orhanu u sprawach religiji b Ukrajini: z 1991 p. po teperisznij czas, http:// www.religion.in.ua/main/history/12072-do-istoriyi-derzhavnogo-organu-u-spravax-religijv-ukrayini-z-1991-r-po-teperishnij-chas.html [dostęp: 2.05.2014].

${ }^{27}$ Relihija i wlada w Ukrajini: problemy wzajemowidnosyn, s. 5.

${ }^{28}$ T. Antoszewskij, L. Kowalenko, Monitoring relihijnoji, s. 15.

${ }^{29}$ Tamże, s. 16. 
Interesujące jest także spojrzenie ukraińskiej Helsińskiej Fundacji Praw Człowieka na działalność W. Juszczenki. Fundacja z aprobatą przyjęła prezydencki postulat stworzenia jednej ukraińskiej prawosławnej Cerkwi. Zaznaczono jednocześnie, że: „Nie można nie zauważyć pozytywnej strony rozwoju tej kwestii, ale jednocześnie taki postulat wydaje się wyprzedzać istniejący stan międzykonfesyjnych stosunków, ze względu na wielość konfliktów między Kościołami" ${ }^{30}$. Zastanawiające jest, że w swoim oficjalnym dokumencie Fundacja akceptuje ideę ingerencji prezydenta Ukrainy w sferę zasadniczo zarezerwowaną dla związków wyznaniowych. Kwestia jednoczenia związków wyznaniowych należy do ich spraw wewnętrznych. One decydują o swojej strukturze wewnętrznej. W systemie demokratycznym państwo nie może być jedną ze stron tego procesu, inicjować łączenia Kościołów w jeden podmiot. Oczywiście, ukraińskie władze państwowe dążą do stabilności wewnętrznej kraju i zdają sobie sprawę, że podział prawosławia na Ukrainie ma charakter przede wszystkim jurysdykcyjny, a nie teologiczny. Z punktu widzenia państwa współpraca z jedną Cerkwią prawosławną, której władze nie znajdują się na terytorium obcego państwa, jest pożądana. Niemniej jednak niewłaściwe jest angażowanie autorytetu państwa przy zagadnieniu ewentualnego zjednoczenia Cerkwi.

Stosunki między państwem a związkami wyznaniowymi zmieniały swój charakter w okresie wyborów parlamentarnych, prezydenckich oraz samorządowych. Kościoły w pewnym sensie stawały się instrumentem polityków, a $\mathrm{z}$ drugiej same też miały ambicje wpływania na politykę. Mimo że udział duchowieństwa w życiu politycznym był pewnym problemem, to zauważalna stała się poprawa $\mathrm{w}$ porównaniu do lat wcześniejszych. Zwłaszcza w latach dziewięćdziesiątych XX w. mówiło się o bliskich kontaktach UCP KP z radykalnym nacjonalistycznym ugrupowaniem UNA-UNSO (Українська Національна Асамблея - Українська Національна Самооборона, Ukraińskie Zgromadzenie Narodowe - Ukraińska Samoobrona Narodowa) ${ }^{31}$.

${ }^{30}$ Przykładowo, mer jednego z miast zabronił przedstawicielom UCP MP udziału w święcie 1000-lecia miasta, zob. tamże.

${ }^{31}$ Szczoriczni dopovidi pro prawa ljudyny. Prawa ljudyny w Ukrajini-2005. Dopowidi prawozachysnych orhanizacij, http://helsinki.org.ua/index.php?id=1150725399 [dostęp: 2.05.2014]. 
Wydany w 2007 r. raport dotyczący przestrzegania praw człowieka na Ukrainie wskazywał, że: ,Wybory Prezydenta w 2004 roku pokazały najgorsze formy włączenia Cerkwi do brudnej agitacji, ale także stały się przykładem możliwości wspólnego udziału różnych Kościołów i religijnych organizacji w obronie wartości społeczeństwa obywatelskiego"32. Autorzy raportu dostrzegali powolną zmianę obyczajów politycznych, dostrzegając przy tym pozytywną rolę Kościołów. Kwestia udziału duchownych w wyborach dotyka dwóch zasadniczych spraw. Z jednej strony, odnosi się do posiadania praw wyborczych przez duchownych, a także do możliwości ich udziału w wyborach jako kandydatów na stanowiska pochodzące $\mathrm{z}$ wyborów. W polskiej rzeczywistości politycznej jest to sprawa nieistniejąca, obecna jedynie w okresie II RP. Jednakże na Ukrainie duchowni prawosławni brali czynny udział w wyborach ${ }^{33}$.

W 2006 r. z inicjatywy prezydenta W. Juszczenki miało miejsce spotkanie z przedstawicielami Ogólnoukraińskiej Rady Kościołów i organizacji religijnych, którego rezultatem było podpisanie deklaracji przeciwko wykorzystywaniu autorytetu związków wyznaniowych w przedwyborczej agitacji ${ }^{34}$. Krok ten był skierowany przeciwko polityzacji życia religijnego. Jednakże, jak wskazywali niektórzy komentatorzy, powinien nastąpić dużo wcześniej przed wyborami. Takiego zdania był ekspert RISU, Jurij Reszetnikow ${ }^{35}$.

Obserwatorzy ukraińskiego życia politycznego zauważali stopniowe zmniejszenie politycznej aktywności związków wyznaniowych. Ponadto, partie polityczne dostrzegły stosunkowo małą efektywność agitacji w świątyniach. Wydaje się także, że same związki wyznanio-

${ }^{32}$ Zob. W. Pawluczuk, Ukraina, s. 73, 158-162.

${ }^{33}$ T. Antoszewskij, L. Kowalenko, I. Sklenar, Monitoring relihijnoji swobody w Ukrajini: osoblywa uwaha do stany relihijnoji tolerantnosti, Lwiw 2006-2007, s. 59, http://www.irs. in.ua/index.php?option $=$ com_content $\&$ view $=$ article $\&$ id $=123 \% 3 \mathrm{~A} 1 \&$ catid $=38 \% 3 \mathrm{Apub} \&$ Item $\mathrm{id}=65 \&$ lang=uk, [dostęp: 4.05 .2014$]$.

${ }^{34}$ Autorzy raportu podają m.in., że 15 duchownych diecezji chmielnickiej UCP KP zasiadało w różnych radach lokalnych, zob. tamże. Kwestia kandydowania do różnych ciał przedstawicielskich nie dotyczyła Kościoła Rzymskokatolickiego na Ukrainie oraz Ukraińskiej Cerkwi Greckokatolickiej, które powołując się na katolicką naukę społeczną były przeciwne takiemu udziałowi duchownych w polityce.

${ }^{35}$ T. Antoszewskij, L. Kowalenko, I. Sklenar, Monitoring relihijnoji swobody, s. 59. 
we próbowały poluzować swoje związki z partiami politycznymi ${ }^{36}$. Nie oznacza to oczywiście całkowitego wyeliminowania związków kościołów z polityką. Można jednakże zauważyć, że był to pewien symboliczny gest w kierunku rozdzielenia sacrum od profanum.

Przełomowym rokiem dla stosunków pomiędzy państwem a związkami wyznaniowymi był, przede wszystkim w ich ocenie, rok 2010. W wyniku wyborów prezydenckich głową państwa ukraińskiego został Wiktor Janukowycz. Kościoły i niezależni obserwatorzy zgodnie uznali, że relacje kościołów i państwa znacznie pogorszyły się, co wynikało z przyjętej przez W. Janukowycza koncepcji wzajemnych relacji. Pod koniec 2010 r. internetowy portal Religia na Ukrainie zwrócił się do ekspertów z pytaniem o podsumowanie mijającego roku w dziedzinie relacji państwowo-wyznaniowych. Szef Ukraińskiego związku wolności religijnej, Wiktor Jeleński, stwierdził wyraźnie, że: „Głównym wydarzeniem religijno-obywatelskiego życia w 2010 r. stało się pragnienie władzy złamania modelu państwowo-kościelnych relacji, który zdał egzamin na Ukrainie i przewidywał równość głównych aktorów religijnej sceny państwa (...)"37. Pierwsze posunięcia prezydenta Janukowycza wskazywały, że ma odmienną koncepcję relacji ze związkami wyznaniowymi niż jego poprzednik. Można powiedzieć, że jego tzw. promoskiewskość miała także swój wymiar religijno-eklezjologiczny. W. Janukowycz wyraźnie podkreślał swoje związki z UCP PM, która na Ukrainie ma opinię Kościoła powiązanego z Kremlem.

Dwaj inni obserwatorzy ukraińskiego życia politycznego, Myrosław Marynowycz, prezydent Instytutu Religii i Społeczeństwa Ukraińskiego Katolickiego Uniwersytetu oraz Mychajło Czerenkow z fundacji Duchowe Odrodzenie wskazali jako na moment przełomowy obecność patriarchy Cyryla na inauguracji prezydentury W. Janukowycza i udzielenie mu błogosławieństwa. Wskazywano, że została tym samym złamana wcześniejsza tradycja wspólnego błogosławieństwa udzielanego przez przedstawicieli innych Kościołów.

${ }^{36}$ J. Reszetnikow, 2006 rik: relihijnyj wymir, http://risu.org.ua/article_print.php?i$\mathrm{d}=14061$ \&name=analytic\&_lang=ua\& [dostęp: 1.04.2014].

37 2010-2011: Pidsumky i perspektywy w ocinkach ekspertiw, http://risu.org.ua/ua/index/ monitoring/society_digest/39940/[dostęp: 1.04.2014]. 
M. Marynowycz stwierdził, że: „Model jaki realizuje prezydent Wiktor Janukowycz i jego ekipa to model uprzywilejowanej i w rzeczywistości państwowej Cerkwi, w którym [modelu - M.S.] innym Cerkwiom i organizacjom religijnym pozwala się funkcjonować w drugorzędnych rolach" ${ }^{38}$. Akcentowanie przez W. Janukowycza jako prezydenta przynależności do UCP MP uważano za przejaw wyboru nie tylko religijnego, ale także geopolitycznego ${ }^{39}$.

Cytowany już M. Marynowycz stwierdził również, że: ,(...) w UPC MP i w ekipie Prezydenta Janukowycza wzięto kurs na utwierdzenie monopolu «jedynej prawdziwej» Cerkwi, monopolu, który od niedawna ma elegancką tabliczkę «ruskiego świata»"

Koncepcja „ruskiego świata” (ros. русский мир, ukr. російський світ) jest propagowana przez moskiewskiego patriarchę Cyryla. Jej istotą jest przekonanie o religijnej jedności Rosji, Ukrainy i Białorusi. Patriarcha Cyryl zauważył kiedyś, że: „Jądrem Ruskiego świata dzisiaj jest Rosja, Ukraina i Białoruś; i święty Ławrentij Czernichiwski wyraził tę ideę znaną frazą: «Rosja, Ukraina i Białoruś to święta Ruś»" "41. Przedstawiciele Cerkwi Prawosławnej Patriarchatu Kijowskiego, Ukraińskiego Kościoła Greckokatolickiego, a także wielu ukraińskich polityków, zdecydowanie przeciwstawili się tej koncepcji widząc $\mathrm{w}$ niej imperialne dążenie prawosławia rosyjskiego. Widzieli w tym także próbę zaburzenia relacji między państwem a związkami

38 Tamże.

${ }^{39} \mathrm{~W}$ piśmie „Nacionalna bezpeka i oborona” jako znaczące przyjęto umieszczenie na oficjalnej stronie internetowej prezydenta Ukrainy informacji, że: „Głowa państwa modli się w Ławrze Zaśnięcia Matki Bożej”. Wskazywano, że W. Janukowycz nie reprezentuje tylko swojej religijności, ale reprezentuje przede wszystkim państwo, zob. Cerkowno-relihijna sytuacjija $i$ derżawno-konfesijni widnosyny w Ukrajini: pidsumky desjatlittja, tendencijii i problemy, „Nacionalna bezpeka i oborona” 2011, nr 1-2(119-120), s. 5.

40 2010-2011: Pidsumky i perspektywy.

${ }^{41}$ Wystup Patriarcha Kyryła na widkrytti III Asembleji fondu 'Ruskij swit', http:// religions.unian.ua/orthodoxy/290285-vistup-patriarha-kirila-na-vidkritti-iii-asamblejifondu-ruskiy-svit.html [dostęp: 7.05.2014]. Patriarcha był świadomy możliwego odbioru idei „ruskiego świata” i zapewniał, że nie jest on politycznym narzędziem Federacji Rosyjskiej, tamże. Ławretnij Czernihiwski (1868-1950), był mnichem klasztoru Troickiego w Czernihowie, cieszył się wielkim szacunkiem wiernych. Zob. też A. Szeptycki, O jedność słowiańskiego prawosławia, „Nowa Europa Wschodnia” 2011, nr 1, s. 64-75. 
wyznaniowymi na Ukrainie. Kościoły obawiały się, że popieranie tej idei przez prezydenta Janukowycza doprowadzi do ich marginalizacji.

W 2013 r. Centrum Razumkowa opublikowało sondaż przeprowadzony wśród Ukraińców, w którym zadano im kilka pytań odnoszących się do zagadnienia „ruskiego świata”. W odpowiedziach na pytania uwzględniono także konfesyjną przynależność badanego. Na pytanie: Czy doktryna „ruskiego świata” skierowana jest na:

a) duchowe zjednoczenie bratnich narodów rosyjskiego, ukraińskiego i białoruskiego

b) restaurację Rosyjskiego Imperium

c) trudno powiedzieć.

Wśród respondentów należących do UCP PM 70,9\% wskazało pierwszą odpowiedź, 15,1\% drugą, a 14\% trzecią. Wśród respondentów przynależnych do Patriarchatu Kijowskiego pierwszą odpowiedź wybrało $20 \%$, drugą $69,5 \%$, a trzecią $10,5 \%$. Inaczej wyglądały odpowiedzi respondentów zaliczonych do grupy ,inni prawosławni”: $49,4 \%, 38,6 \%$ oraz $12,0 \%$. Podano także odpowiedzi osób należących do Kościoła greckokatolickiego z adnotacją, że nie była to grupa reprezentatywna. Tu odpowiedzi kształtowały się następująco: pierwsza odpowiedź $2,5 \%$, druga $95 \%$, a trzecia $2,5 \%{ }^{42}$.

Z powyższych danych dość jednoznacznie wynika, że przedstawiciele kościołów, poza UCP PM, z dość dużym dystansem podchodzili do idei „ruskiego świata”. Można nawet zaryzykować twierdzenie, że się tej koncepcji obawiano.

Problemem, który bardzo poruszył przedstawicieli związków wyznaniowych na Ukrainie była kwestia nowelizacji ustawy o wolności wyznania i organizacjach religijnych, do której dążył prezydent Janukowycz. W kwietniu 2011 r. prezydent po raz pierwszy spotkał się z przedstawicielami Ogólnoukraińskiej Rady Kościołów i organizacji religijnych. Tematem spotkania miała być przygotowywana nowelizacja wspomnianej ustawy. W. Janukowycz obiecał, że zmiany nie nastąpią bez akceptacji ze strony ukraińskich związków wyznaniowych. W rzeczywistości ustawa ta została przyjęta pomimo sprzeciwów m.in. Rady Kościołów.

${ }^{42}$ Relihija i wlada w Ukrajini: problemy wzajemnowidnosyn, s. 15. 
W listopadzie 2012 r. prezydent zdecydował o podpisaniu znowelizowanej ustawy. Wprowadzono do niej zasadniczo tylko kilka zmian, jednakże zdaniem ukraińskich prawników oraz przedstawicieli kościołów, bardzo znaczących. Zmieniono brzmienie artykułów, na podstawie których dokonywana jest rejestracja związków wyznaniowych. Chodziło o artykuły nr 13 i 14. Artykuł 13 w dotychczasowej redakcji brzmiał: „Organizacja religijna z chwilą rejestracji jej statutu (ustawy) nabywa uprawnienia osoby prawnej (...)"43. Słowa „z chwilą rejestracji” zamieniono na „od dnia jej państwowej rejestracji”" ${ }^{4}$. Podobnie w art. 14, sformułowanie: ,W celu otrzymania przez gminę wyznaniową osobowości prawnej (...)"45, zamieniono słowami: „W celu rejestracji statusu (ustawy) (...)"46.

Eksperci Rady Najwyższej zgłaszali zastrzeżenia do powyższych zmian sugerując, że niejasność sformułowań może się przyczynić do wprowadzenia ,podwójnej” rejestracji religijnych organizacji. Wskazywali, że będzie rodzić to konieczność: „a) państwowej rejestracji dla nabycia statusu osoby prawnej; b) rejestracji statutów (ustaw) organizacji religijnych" ${ }^{47}$. Zauważano, że dotychczas rejestracja statutów miała miejsce jeden raz w celu nabycia osobowości prawnej. Nowelizacja może spowodować skargi związków wyznaniowych na pogwałcenie ich wolności zagwarantowanych w konstytucji.

Bardzo istotna zmiana dotyczyła także zakresu kontroli, której poświęcony jest art. 29 wspomnianej ustawy (Państwowa kontrola przestrzegania ustawodawstwa o wolności sumienia i religijnych organizacji). W dotychczasowym brzmieniu ustawa przewidywała, że: „Państwową kontrolę w zakresie przestrzegania ustawodawstwa Ukrainy o wolności sumienia i organizacjach religijnych realizują

${ }^{43}$ T. Szyszlak, Lwowskie sacrum, s. 321.

${ }^{44}$ Zakon Ukrajiny pro wnesennja zmin do dejakych spramowujetsja ta koordynujetsja czerez widpowidnych ministriw, a takoż Derżawnoho kosmicznoho ahenstwa Ukrajiny, BBP 2014, No 5, ст. 62, http://zakon4.rada.gov.ua/laws/show/5461-17/print1360192991986785 [dostęp: 7.05.2014].

${ }^{45}$ T. Szyszlak, Lwowskie sacrum, s. 321.

${ }^{46}$ Zakon Ukrajiny, zob. przyp. 46.

${ }^{47}$ Relihija i wlada w Ukrajini: problemy wzajemowidnosyn, s. 8. 
terenowe Rady Deputatów Ludowych i ich komitety wykonawcze"48. Nowelizacja całkowicie zmieniła ten artykuł. W nowej wersji otrzymał on następujące brzmienie: „Zapewnienie wykonania i przestrzegania ustawodawstwa o wolności sumienia, światopoglądu, wyznania i organizacjach religijnych znajduje się w kompetencji centralnych organów wykonawczych władzy, które zabezpieczają kształtowanie i realizację polityki wyznaniowej państwowa, oraz innych centralnych organów władzy wykonawczej, organów prokuratury, miejscowych organów władzy wykonawczej i organów miejscowej administracji"49. Eksperci wskazywali, że nadanie uprawnień kontrolnych prokuraturze kłóci się z ustawodawstwem ukraińskim. Przede wszystkim z ustawą o prokuraturze, w której określone zostały jej kompetencje ${ }^{50}$. Ponadto, analitycy z Instytutu Wolności Religijnej wskazywali na brak określenia formy i metod kontroli ${ }^{51}$.

Przedstawiciele związków wyznaniowych protestowali przeciwko tym zmianom uważając, że utrudnią one działalność związków wyznaniowych. Ogólnoukraińska Rada Kościołów i organizacji religijnych bezskutecznie zwracała się do prezydenta W. Janukowycza o zawetowanie ustawy, w której całkowicie pominięto ich postulaty. Przedstawiciel UCP KP zauważył, że kościoły w latach 2003-2004 wypracowały wraz z ekspertami koncepcję relacji państwa i związków wyznaniowych. Jednocześnie stwierdził on, że: „Latami prosimy, aby parlament rozpatrzył je, a zamiast tego przyjmuje się to, przeciwko czemu protestujemy"52.

Przyjęcie nowelizacji ustawy o wolności wyznania przyczyniło się do pogorszenia i tak dość napiętych stosunków między władzą państwową a związkami wyznaniowymi. Przedstawiciele głównych wyznań Ukrainy, poza UCP PM, wyrażali przekonanie o marginalizacji ich roli. Szczególnie wyraźnie dostrzegano brak współpracy z urzędu-

${ }^{48}$ T. Szyszlak, Lwowskie sacrum, s. 327.

${ }^{49}$ Zakon Ukrajiny, zob. przyp. 46.

${ }^{50}$ Relihija i wlada w Ukrajini: problemy wzajemowidnosyn, s. 8.

${ }^{51}$ Nabuty czynnosti rezonansni zminy do Zakonu pro swobodu sowisti ta relihijni orhanizaciji, www.irs.in.ua [dostęp: 21.03.2014].

${ }^{52}$ W UPC KP nahołoszujut', szczo suczasnyj relihijnyj zakon u bilszij miri własztowuje wsi konfesiji, tomu wnosyty żodnych zmin ne potribno, http://risu.org.ua/ua/index/all_news/ state/legislation/50259/ [dostęp: 21.03.2014]. 
jącym prezydentem. Jego polityka wyznaniowa w ich odczuciu nie była odpowiednia dla wielowyznaniowej Ukrainy. Przedstawiciele Rady Kościołów odnosili wrażanie lekceważenia ze strony prezydenta. Przykładem może być zaplanowana wiele miesięcy wcześniej wizyta członków Rady w Brukseli na zaproszenie Unii Europejskiej. Wizyta ta została odwołana, gdyż na ten czas W. Janukowycz wyznaczył termin wizyty przedstawicieli Rady u siebie.

Napięcie w stosunkach pomiędzy władzą państwową, zwłaszcza ośrodkiem prezydenckim, a związkami wyznaniowymi stało się jeszcze bardziej zauważalne pod koniec 2013 r. w czasie masowych protestów społeczeństwa ukraińskiego przeciwko polityce prezydenta W. Janukowycza. Punktem zapalnym była odmowa podpisania przez niego umowy stowarzyszeniowej z UE. Wśród protestujących na tzw. Euromajdanie byli także przedstawiciele wyznań obecnych na Ukrainie. Ich obecność miała charakter duszpasterski. Ukraińskie Kościoły zdecydowanie starały się nie dopuścić do rozlewu krwi. Obecność duchowieństwa na Majdanie spotkała się z dezaprobatą strony rządowej. Charakterystyczne jest, że oficjalnie Ministerstwo Kultury (jemu podlegają kwestie wyznaniowe po likwidacji Komitetu do spraw religii) wystąpiło na początku stycznia 2014 r. jedynie przeciwko Ukraińskiemu Kościołowi Greckokatolickiemu. Ministerstwo argumentowało, że Kościół nie miał pozwolenia od kijowskiej administracji na publiczne sprawowanie nabożeństw ${ }^{53}$. Taka reakcja władzy wywołała duże poruszenie wśród ukraińskiego społeczeństwa $^{54}$ i została uznana za próbę nacisku na Kościół ${ }^{55}$.

Mimo że Ukraińska Cerkiew Prawosławna Moskiewskiego Patriarchatu dystansowała się na początku od jakiegokolwiek zaangażowania w Euromajdan, to w obliczu rosyjskiej aneksji Krymu zareagowała dość jednoznacznie. Metropolita Onufry zwrócił się do Prezydenta Władimira Putina $\mathrm{z}$ apelem o niewprowadzanie wojska na teren Ukrainy i nienaru-

${ }^{53}$ Minkultury ne maje namiru poperedżaty inszi cerkwy krim UGCK, pro nezakonne bohostużinnja, http://risu.org.ua/ua/index/all_news/state/church_state_relations/54952/[dostęp: 6.05.2014].

${ }^{54}$ Zob. Lyst Minkultu do UGCK spyczynyw oburennja sered lwiwjan, http://risu.org.ua/ ua/index/monitoring/society_digest/54934 [dostęp: 6.05.2014].

${ }^{55}$ Lyst Minkultu je oczewydnym tyskom na Cerkwu, http://risu.org.ua/ua/index/all_news/ state/church_state_relations/54918/[dostęp: 6.05.2014]. 
szanie jedności kraju. Metropolita wystosował także apel do patriarchy Cyryla o wpłynięcie na prezydenta Federacji Rosyjskiej ${ }^{56}$. Praktycznie wszystkie związki wyznaniowe na Ukrainie starały się apelować o pokojowe rozstrzygnięcie konfliktu oraz zgodę narodową potrzebną do uspokojenia sytuacji na Ukrainie po pozbawieniu stanowiska W. Janukowycza ${ }^{57}$.

Podsumowując całość rozważań można stwierdzić, że Ukraina od momentu ogłoszenia niepodległości próbuje konstruować swój model relacji pomiędzy państwem a związkami wyznaniowymi w rzeczywistości społeczeństwa wielowyznaniowego. Konstytucja i ustawa o wolności sumienia i organizacjach religijnych wydają się być solidnym fundamentem regulującym stosunki pomiędzy państwem i Kościołami, choć nowelizacja tej ostatniej wprowadzona w 2012 r. - według specjalistów ukraińskich - skomplikowała te relacje. Nie do końca sprecyzowana jest także kwestia rejestracji związków wyznaniowych. Ponadto, wzajemnym relacjom nie służy brak stabilności w sferze administracyjnej. Zbyt często dochodziło bowiem do zmian organu kompetentnego w sprawach wyznaniowych i jego umiejscowienia w hierarchii urzędowej.

\section{BIBLIOGRAFIA}

Babinow J.A., Poszukiwania ukraińskiego modelu stosunków państwowo-religijnych, „Nomos” 2001, nr 34-36.

Cerkowno-relihijna sytuacjija $i$ derżawno-konfesijni widnosyny $w$ Ukrajini: pidsumky desjatlittja, tendencijii i problemy, „Nacionalna bezpeka i oborona" 2011, nr 1-2(119-120).

Pawluczuk W., Ukraina. Polityka i mistyka, Kraków 1998.

Relihija i wlada w Ukrajini. Informacijni matariali do Kryhtoho stotu na temy Derżawno konfesijni widnosyny w Ukrajini stanom na 2013 rik: ruch do partnerstwa derżawy i Cerkwy czy do kryzy wzajemin?, Kyjiw 2013.

Szeptycki A., O jedność stowiańskiego prawosławia, „Nowa Europa Wschodnia" 2011, nr 1 .

${ }^{56}$ Ukraina 2014: suspilno-politycznyj konflikt i cerkwa, Kijów 2014, s. 8

${ }^{57}$ Zob. Zwernennja keriwnikiw Cerkow i relihijnych orhanizacij do swoich wirnych ta wsich ljudej dobroji woli y zwjazku z suspilno-politycznoju sytuacujeju w Ukrajini, tamże, s. 11. 
Szeptycki A., Podziaty religijne na Ukrainie, w: Religia w stosunkach międzynarodowych, red. A.M. Solarz, H. Schreiber, Warszawa 2012.

Szyszlak T., Lwowskie sacrum, kijowskie profanum. Grekokatolicyzm w ukraińskiej przestrzeni publicznej od pierestrojki do pomarańczowej rewolucji, Warszawa 2012.

Ukraina 2014: suspilno-politycznyj konflikt i cerkwa, Kijów 2014.

THE RELATIONSHIP BETWEEN THE STATE AND THE RELIGIOUS ASSOCIATIONS IN SOVEREIGN UKRAINE

\section{Summary}

The paper presents the relationship between the state and religious associations in Ukraine. After Ukraine gained independence in year 1991 it was required that the matters concerning religious confessions be regulated according to democratic standards. Among the legislations were the Bill on freedom of confession and religious organisations and the new constitution which defines the basic rules of state-religion relations.

The relationship between the religious associations and state are analized by Ukrainian churches and non-governmental organisations such as Ukrainian Helsinki Human Rights Union, Razumkow Center and the Institute for Freedom of Religion.

It is commonly agreed that until 2010 the relationship between the state and religious organisations were correct. However, the religious policy of state changed after Wiktor Janukowycz had become the president. The administrative organs for confessions were altered and the Bill on freedom of confession and religious organisations was amended. The religious associations saw these changes as an attempt to deprive them of their independence

Ttumaczenie własne autora

Key words: Ukrainian ecclesiastical law, Ukrainian law on religion, freedom of religion, religious organisations in Ukraine, state-church relations

Słowa kluczowe: ukraińskie prawo wyznaniowe, wolność wyznania, związki wyznaniowe na Ukrainie, stosunki państwo - Kościół 